\title{
Cartas del editor de México a través de los siglos*
}

Santiago Ballescá

A Hugo Vargas, editor de Riva Palacio

$\mathrm{E}$ n el Archivo de Vicente Riva Palacio, conservado en la Universidad de Texas, en Austin, hallé 25 cartas de Santiago Ballescá; 23 de ellas dirigidas a Vicente Riva Palacio, una a Juan de Dios Arias y otra a Agapito Ortiz de Jiménez, ambos colaboradores del general. Su principal interés radica en que Ballescá fue el editor de México a través de los siglos y en que en dichas cartas se revelan muchas cosas

* Presentación, transcripción y notas de José Ortiz Monasterio. que ignorábamos: el número de suscriptores de la obra, su opinión negativa del trabajo de Chavero, el lento ritmo de los escritores para entregar su trabajo, los problemas causados por la muerte de Juan de Dios Arias y cómo Enrique de Olavarría y Ferrari entró al quite, la forma en que Vigil logró que se le pagara dos veces el trabajo, etcétera.

Ballescá fue, de hecho, el primer lector de la obra y su recepción tiene por ello gran interés. Encargado por su padre de atender el negocio editorial de la familia en México, logró establecer una estrecha -pero siempre 
respetuosa-amistad con Riva Palacio. Fue propiamente el editor del México: sugería cómo mejorar la presentación de los originales y cuidaba de que la ortografia fuera correcta, proponía ilustraciones para los capítulos y tenía a su cargo a los dibujantes, pedía cambios cuando los autores de plano erraban, mandaba a Barcelona los originales para su corrección final. Porque la impresión de la obra estuvo a cargo de Espasa, quien según estas cartas fue el que obtuvo el mayor beneficio de la obra.

Más allá del México, estas cartas interesan porque sabemos demasiado poco de nuestra historia editorial, y en ellas se retrata el mundo de un editor y la organización de su negocio. Entre otras cosas, se viene abajo la imagen de la industria editorial del siglo XIX como un negocio incipiente: basta atender a los tirajes que se mencionan y a las dimensiones de la negociación de Ballescá.

Además, Ballescá era un escritor muy correcto y ameno por lo cual el lector curioso no quedará defraudado.

José Ortiz Monasterio

Muy señor mío y distinguido amigo:

Tengo el honor de ponerme a las órdenes de usted en esta ciudad, a la que llegué el día 14 del actual después de haber realizado el viaje más feliz que desearse pueda.

Siendo como usted sabe el punto principal de mi viaje el mejor y más violento arreglo de los negocios en que usted me ha dispensado la honra de tomar una parte activísima, de preferencia y sin perder momento me ocupé de ellos desde mi llegada, y hoy puedo ya suplicar a usted que por conducto de mi hermano político Alberto L. Palacios, se sirva remitirme los originales de sus tradiciones, en su totalidad si las tiene usted escritas o la parte que tenga en caso contrario; siendo de advertir que convendría mejor que dichos originales viniesen de una sola vez, no por otra cosa sino porque el artista a quien se encargue su ilustración pueda de una vez también trazar su plan general. Los editores que han aceptado mis proposiciones para la publicación del libro de usted son los mismos que editan la colección de "Arte y Letras" que usted conoce y de la cual formarán parte las tradiciones de usted. 


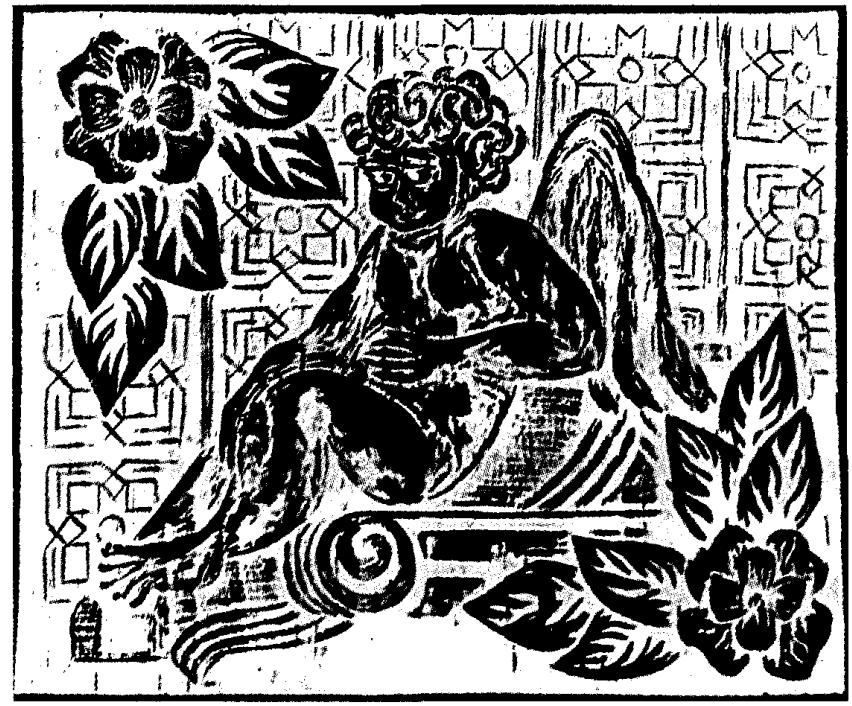

Yo hubiese deseado hallar por parte de la casa editorial alguna oposición a las proposiciones por mí presentadas, para combatirla y vencerla y poder así asentar una pequeña partida al haber de la larga cuenta de gratitud de que le soy a usted deudor; pero gustaron tanto y tan justamente los escritos de usted, que nada pude hacer para encomiar como se merece su mérito. Quedo, pues, tan endrogado con usted como siempre; y no es esto lo que más siento, sino que mi cuenta irá en constante aumento, pensando como pienso continuar usando de la confianza y amistad con que usted me honra.

Piden los editores de "Arte y Letras":

Que se sirva usted dar título general al libro que contendrá las tradiciones o leyendas.

Que al frente conste el nombre de usted como autor que es de ellas.

Que escriba usted originales suficientes a cubrir 350 páginas que serán impresas con los mismos tipos que tiene la obra "Fortuny", que usted conoce y que forma parte de la misma biblioteca.

Suplico a usted que el envío de los originales lo efectúe lo más pronto que le sea posible; pues desde su llegada a ésta a la fecha de la aparición 
del libro tendrán aún que transcurrir algunos meses, debido a que los artistas dejan mucho que desear en el sentido de la formalidad.

Algo más difícil que el asunto de que he tratado se presenta el de la publicación de la otra obra. Creo, sin embargo, poder asegurar a usted que todo saldrá a medida de nuestros deseos; pues si por ahora se presentan algunas dificultades, éstas son sólo de detalle, ya que la idea en general ha sido bien aceptada por la casa que ha de emprender el negocio.

Estas dificultades que ahora se presentan por la magnitud de la empresa que se proyecta, no dudo ni un momento que desaparecerán si, como creo, puedo continuar contando con el apoyo de usted y con la seguridad de que las personas comprometidas trabajarán como es necesario para que una vez comenzada la publicación no tenga que interrumpirse un solo día por falta de originales. Yo ruego a usted se sirva decirme si puedo contar con tales seguridades, única cosa que se necesita para presentar a México a la faz del mundo tal como él es y no como se le juzga aun por hombres que son reputados como sabios y que respecto de ese país sólo saben que no saben nada. Si yo en mi ignorancia crasa lo he podido comprender así en lo poco que he viajado, usted con sobrados conocimientos y con sus largas expediciones debe saber hasta qué punto me quedo corto al expresarme así. Dar muerte a tan añejas preocupaciones y levantar esa República a la altura que le corresponde, es una obra en la que deben interesarse todos los que de buenos mexicanos se precien, y como que en México es grande y levantado el espíritu patriótico, en último resultado pasaré por todo lo que los editores quieran exigirme antes que abandonar la empresa que tenemos en proyecto, porque en este caso no temería confiarlo todo al favor del público mexicano. La obra, pues, se hará y no así como quiera sino de una manera digna del objeto principal a que se destina y digna también de las plumas que han de escribirla.

Repito que lo único que necesito para el logro de esta empresa es la buena amistad de usted; pues contando con ésta nada habrá ya que pueda entorpecer mis planes.

Pido a usted mil perdones por mis continuas molestias; $y$ haciendo votos porque se conserve usted sin novedad me repito afectísimo seguro servidor y amigo que besa su mano

Santiago Ballescá

Casa de usted en ésta, calle Valencia número 340. 
[2] [Membrete:] J. Ballescá y Compañía, centro de suscripciones, México.

Mêxico, 1 de agosto de 1883

Señor general don Vicente Riva Palacio

La Asunción

Distinguido señor y amigo mío:

Salud a toda la colonia.

Acompaño la satisfactoria carta de Espasa, que acabo de recibir, y la publicación a que la misma se refiere. Yá verá usted que hasta los mismos editores se sorprenden de la bondad de lo que mandamos: más se sorprenderán cuando lean los originales literarios, pues no creían ellos ni nadie cree fuera del país que tales cosas puedan llevarse a cabo aquí.

Le ruego a usted encarecidamente que adelante cuanto pueda los originales.

Me dice mi padre que hay mucha gente trabajando en la obra y que todos los socios de la casa Espasa están dispuestos a no perdonar medio, a fin de que todo salga lo mejor posible.

Ya mandé la leyenda así como el prospecto para el tomo, ampliando mi primer pedido a 2000 ejemplares. Di las necesarias instrucciones y manifesté que con los originales remitidos saldría un tomo de buen volumen y no cansado para el lector; dando otras razones en pro de nuestra idea, de que los libros no se deben medir por su tamaño sino por su caliá. Les doy en mi carta mucha prisa; asegurándoles un éxito completo y ofreciéndoles originales cual no otros para nuevos libros, siempre que en el de que se trata queden como buenos catalanes. ¡Olé!

Ruego a usted imponga al señor don Juan de Lámina Grande Arias de lo relativo a la Historia, así como decirle que contestaré de palabra, en alta voz y accionando su atenta epístola del día 25, para lo cual me trasladaré a esa en cuanto me sea posible. Que no olvido la importante parte que tiene en la obra; pues deseo que a mi ida a esa me entregue originales para que el escribiente los copie y con tiempo se arregle todo.

Felicidades sin cuento les desea a todos su verdadero amigo y seguro servidor que besa su mano

Santiago Cromo Chico de Intercalado 

siglos, apartado de correos 13, México.

Casa de usted, México 28 de junio de 1884 Señor general don Vicente Riva Palacio

Presente

Muy señor mío y estimado amigo:

Leí el capítulo 34 y creo que será bueno poner:

Retrato de don Luis de Velasco

Alguna vista antigua de Oaxaca

Alguna vista antigua de Guadalajara

Sepulcro de Cortés

Una vista de Castilleja de la Cuesta

Panteón de los duques de Medina Sidonia

Iglesia de San Francisco, en Texcoco

Algún edificio antiguo de Cholula

A Oaxaca escribí desde el otro día pidiendo vistas. Hoy escribo a Guadalajara, y a Puebla para lo de Cholula.

¿El retr[ato] de Velasco debe ser el de que nos mandaron prueba (el tuerto) o el otro del mismo nombre?

¿Sabe usted cuál sea el edificio de alguno de los hospitales que fundó Zumárraga?

Me informaré de si existe la iglesia de San Francisco en Texcoco y de existir va Cantó a copiarla.

El capítulo 35 lo leeré luego que esté copiado todo y veré todo lo que se le pueda poner; teniendo presente lo que usted me indica.

Cada día aumenta el interés del tomo 2o. Deje usted que esté completo y la gente lo lea aquí y fuera del país.

Tengo el gusto de enviarle pruebas del "Altar de los reyes" y de los "Escudos": creo que le gustarán. También va el prospecto que se ha hecho para la América del Sur. En estos momentos se reparte la obra en todas partes. Pronto recibiremos los artículos de la prensa.

Desea darle un estrecho abrazo su afectísimo amigo y seguro servidor que lo quiere

Santiago Ballescá 
[4] [Membrete:] Ballescá y Compañía, editores, México a través de los siglos, apartado de correos 13, México.

Casa de usted, México 25 de agosto de 1884 Señor general don Vicente Riva Palacio Presente

Muy señor mío y estimado amigo:

Me dijo Felipe que no necesitaba usted el mapa. Como me dijo usted que no corría prisa no quise molestar a García Cubas y se lo había encargado a un corredor de libros.

El libro sobre piraterías que encargó usted en ninguna parte lo hay ni se tienen noticias de él. En el Archivo hay: "Historia manuscrita.Correspondencia de los virreyes al rey y varios documentos referentes a piratas." En la Biblioteca: Piratas de la América y loor a la defensa de las costas de Indias Occidentales, por Abreu, traducción de Buena Maison, edición tercera, 1793.

Esto es lo único de que se tiene noticia y se lo aviso para que me diga usted si necesita que se tomen algunos datos.

Que tenga usted buena salud y que cesen pronto estos tropiezos le desea su afectísimo amigo que lo quiere y besa su mano

Santiago Ballescá

[5]

[Membrete:] Ballescá y Compañía, editores, México a través de los siglos, apartado de correos 13, México.

México 28 de agosto de 1885 Señor don Juan de Dios Arias La Asunción (Presente)

Estimado amigo y señor mío:

He leído la introducción y los tres primeros capítulos, y aunque no me considero competente para juzgar ese importante trabajo, sí creo poder 
asegurar que, como yo, encontrarán en él todos los lectores desapasionados buen decir, buen criterio e imparcialidad, que son las cualidades indispensables en un historiador.

Tengo algunos escrúpulos respecto de esos originales, escrúpulos meramente debidos al escribiente y que me hacen temer faltas especialmente ortográficas en los nombres propios, por lo que me permito suplicarle se sirva dar una última revisada a los referidos capítulos, que le remito; rogándole me los devuelva sin demora para remitirlos a Barcelona.

Es indispensable que antes de despachar mi original vaya muy bien corregido por usted. Al principio del capítulo 2, por ejemplo, habla usted de un coronel Rincón y en la lista de intercalados que para ese capítulo me mandó usted figura ese mismo Rincón con el título de general. En estas cosas le ruego a usted que se fije mucho, porque en España no podrían ni sabrían enmendarlas.

Conviene mucho que el escribiente haga la letra un poco más grande y pareja, es decir, que no escriba una plana con letra microscópica y otra con letra de buen tamaño.

Las erratas de ortografia nada importan; pero sí importa mucho que los nombres propios tanto de poblaciones como de individuos vayan exactos y claros.

En una sola cosa no estoy muy conforme y es en el final de la introducción, sobre cuyo punto le estimaría que hablase con nuestro querido amigo el señor general Riva Palacio; y si, como creo, estima usted justas las ideas de él en el asunto de que trata dicha conclusión, desearía que reformase su plan, dando en los sucesivos capítulos los documentos o fragmentos de ellos que fuesen necesarios y que por su grande extensión no demanden un lugar en el apéndice.

Por falta de originales en Barcelona, me anuncian los señores Espasa que de no hacerles buenas remesas pronto tendrán que suspender los repartos o que dar menos al mes de los que se deben. Esto mataría la publicación, y para evitarlo le suplico a usted muy encarecidamente que me remita todo lo que tenga dispuesto para mandar a Barcelona, así como que continúe escribiendo tanto como pueda para que mensualmente puedan ir buenas remesas.

Yo estoy sumamente abrumado de trabajo; pero quiero ver si puedo el sábado (mañana) o el domingo ir a esa, lo que le estimaré diga al señor general, saludándolo muy afectuosamente de mi parte, lo mismo que a toda su apreciable familia. 
A usted le desea muchas felicidades su amigo afectísimo y seguro servidor

Santiago Ballescá

[6] [Membrete:] J. Ballescá y Compañia, editores, México, apartado de correos 13, dirección telegráfica: Ballescá.- México.

México 14 de octubre de 1886 Señor general don Vicente Riva Palacio

Madrid

Muy estimado señor y distinguido amigo:

Recibí ayer y leí con mucha satisfacción la apreciable de usted fechada en París el 24 de septiembre, sabiendo por ella que después de los sufrimientos y molestias naturales de una operación se encontraba ya del todo bien. De todo corazón lo felicito a usted y deseo que la presente lo halle ya establecido y tranquilo en la capital de mi patria rodeado de todas las consideraciones debidas más que a su alto carácter oficial a sus merecimientos personales, los que espero serán más estimados en esa que en México.

La salida de usted de aquí me dejó en la orfandad de un amigo verdadero que me alentaba siempre que era necesario con sus sabios consejos. Desde que se marchó usted no hablo con nadie ni tengo a quién referir mis cuitas: me paso el día trabajando duro y parejo y por la noche emprendo mudo y resignado el camino del solitario Mixcoac en donde, para no acostarme a la hora de las gallinas, me entretengo inocentemente en echar al aire dulces melodías sobre temas de "Las tres gracias", "EI barón de la Castaña" y otras obras escogidas del clásico repertorio de don Pancho. La inmensa familia canina del pueblo suele contestar mis armoniosos sones con aullidos salvajes; pero yo confío que con el tiempo lograré introducir el buen gusto musical entre aquellos canes.

Algunos días antes de que falleciese nuestro pobre amigo don Juan [de Dios Arias] empezó a escribir Enrique [de Olavarría y Ferrari] con 


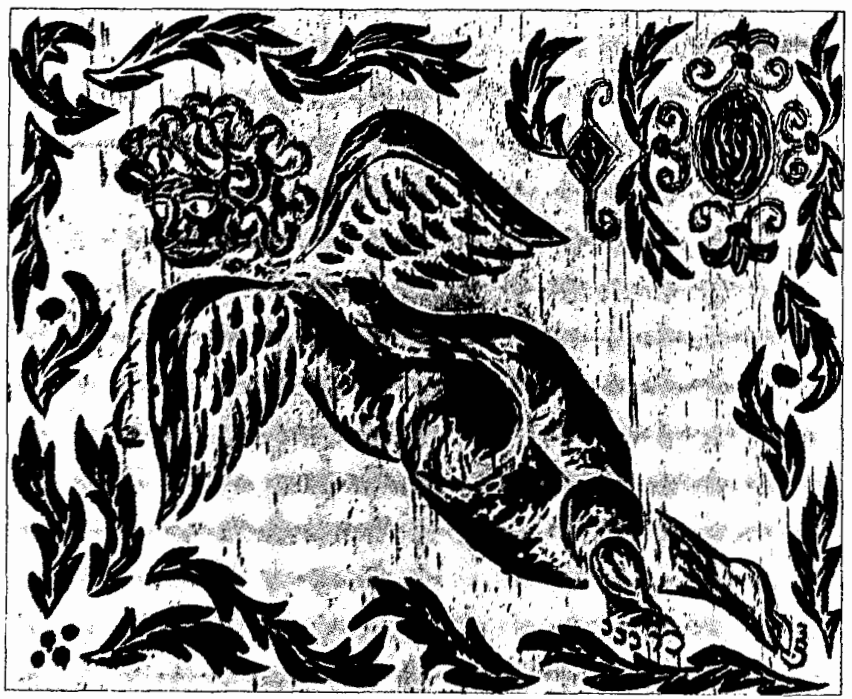

mucho miedo pero con buenos deseos de salir bien de su empresa: su primer capítulo es el XvII; le suplico a usted lo lea tan pronto como esté impreso y me dé su opinión, que creo será favorable. Ha querido Enrique antes de seguir adelante presentar bien coordinados en un solo capítulo todos los acontecimientos anteriormente referidos de una manera desordenada y sin un plan fijo. Creo que ha conseguido su objeto y que nadie podrá quejarse cuando al terminar la obra se haga público el cambio de autor. Por lo demás he pasado y sigo pasando muchas penas por la falta de originales debida especialmente primero a la demora de don Juan y después a su larga enfermedad.

El señor Vigil no hay manera que salga de su paso, y mucho he conseguido con convencerlo al fin de que en una Historia General salen sobrando tantos discursos y documentos inmensos sin verdadero interés y propios sólo para alargar indefinidamente la obra con perjuicio mío y fastidio de los suscritores [sic]. Zárate estuvo mandando originales con regularidad hasta hace unos dos meses en que empezó a prepararse para renunciar [a] la secretaría de gobierno de Veracruz y volver a ésta: llegó anoche y espero que pronto seguirá trabajando. 
Cada día son mayores mis deseos de concluir la obra, no sólo para verme libre de tanto trabajo y cuidado, sino porque entonces creo resarcirme de los quebrantos que ahora sufro.

Como verá usted por el anuncio que acompaño, han concluido los dos tomos. Con este motivo estoy haciendo una nueva y activa propaganda, de cuyos resultados no puedo todavía decir a usted nada.

Ayer estuve con su muy apreciable familia; todos están bien. Poco voy por la casa de usted porque he estado muy ocupado y en las noches tengo que irme al pueblo por tener enfermo el más chico de mis hijos. Además no puedo acostumbrarme a la falta de usted y naturalmente la siento más cuando hablo con los suyos. Todos los días pregunto por todos al organista Felipe; por él he sabido los detalles del viaje de usted.

Mi suegra y las muchachas han agradecido mucho sus recuerdos y me encargan que salude a usted muy afectuosamente.

Ya sé que en pleno París ha seguido usted comiendo a la mexicana. Supongo que lo mismo hará usted en Madrid, lo cual será un motivo más para que cuando yo haga mi viaje me abone a la mesa de usted para saborear esos guisos con la sal y pimienta de su conversación.

Si mis cartas no hubiesen de fastidiar a usted le escribiría seguido. En espera de sus gratas órdenes queda de usted amigo afectísimo y seguro servidor que besa su mano

Santiago Ballescá

[7] [Membrete:] J. Ballescá y Compañía, editores, México, apartado de correos 13, dirección telegráfica: Ballescá.- México.

México 30 de junio de 1887 Señor general don Vicente Riva Palacio

Madrid

Mi muy estimado señor y querido amigo:

Si es que sus muchas ocupaciones le dejan tiempo para acordarse alguna vez de este su pobre editor, creo que será para rezar un sudario por el descanso de su alma, en vista del silencio que he guardado aun después 
de recibir su grata última, que no contesté oportunamente porque ardía en deseos de hacerlo verbalmente. Ya que mi suerte me pone en el caso de no poderle dar a usted un abrazo por ahora, debo explicarle que no por falta sino por sobra de cariño hacia usted dejé de escribirle durante tanto tiempo; pues lo he empleado todo en combinar planes para emprender el vuelo a la patria más con deseos de gozar de cerca con los triunfos de usted que por otro motivo. Pero como que el hombre pone y Dios dispone, de mí dispuso que, en vez de saborear las conversaciones de usted me solace con las agudezas de Álvarez y del coronel, y me consuele admirando la actividad de estos dos jóvenes y su prodigiosa inteligencia mercantil.

Yo sigo en mis trece, y a fuer de buen catalán no quito el dedo del renglón; así que si Dios no dispone otra cosa y usted no quita Madrid, antes de abril próximo, pienso darle a usted un susto mayúsculo anunciándome en los umbrales de su palacio con un soberbio sol bemol aunque sea a media noche, que para artistas de mi pelo aquel astro no se pone nunca.

Pienso reunirme, como el célebre general que usted conoce, con todo y familia en marzo de 88 para pasar una temporada en la corte y seguir luego a Barcelona, en donde deseo establecerme para que no me sigan explotando los editores y para demostrar a usted que si los hay apáticos y poco amantes del buen nombre de los autores también los hay que no se cuidan sólo de su interés particular. Hasta hoy puede decirse que yo he trabajado para los moros; ya tengo ganas de hacerlo para los cristianos.

Salvo que se me presente alguna nueva calamidad de las que con tanta abundancia me han llovido desde que empezamos el México creo que puedo prosperar más yéndome a Barcelona que estando aquí recibiendo órdenes de los editores. La casa de aquí quedará a cargo de los dependientes y desde Barcelona yo la dirigiré y la surtiré de todo aquello que mi práctica me aconseje sea bueno para este país, al mismo tiempo que me dedique a publicar las obras que ahora sólo edito de nombre con todas las desventajas pero sin ninguna ventaja de tal editor.

Aunque sé todo lo que le repugnan a usted las cosas mercantiles me atrevo a pedirle su opinión acerca de mi plan.

Deploro todo lo que con Espasa le ha sucedido a usted y le ruego que no me culpe de nada; pues de mayores inconsecuencias he sido y soy yo víctima.

El señor Zárate ya terminó su tomo. Falta ahora acabar el de Vigil y 
el de Olavarría. Si hasta ahora con los tres sólo han podido darse dos o tres cuadernos al mes, no sé en lo sucesivo lo que va a suceder ni es fácil que presuma yo cuándo acabará la obra. La cachaza de Vigil no tiene igual ni la tiene su monomanía por llenarlo todo de discursos, brindis, documentos y otras zarandajas que sólo sirven para alargar indefinida mente el tomo, el cual al paso que vamos sólo puede terminar con la vida del autor. En cuanto a Olavarría, trabaja con verdadero empeño; pero como le vino ese encargo como un bombazo y tiene que escribir a la vez la obra religiosa que me tenía empezada, no puede por esta razón ir tan de prisa como yo quisiera. Y a este paso sucede lo que es natural; que el público se aburre y que el número de suscritores va cada día a menos, quedando hoy unos 2800 entre nuevos y antiguos de más de 7000 que empezaron. Ya supondrá usted lo que esto significa para mí teniendo el compromiso de recibir y pagar 5000 ejemplares. ¡Buena diferencia habría si todos hubiesen cumplido como usted!

Con un éxito que no pasa de mediano estoy repartiendo la obra religiosa de Olavarría, de la que le mando a usted un cuaderno de muestra.

Mañana debo firmar con Juan de Dios Peza un contrato para que me escriba una novela histórica de la época de la guerra con los americanos, titulada El capitán Miguel. ¿Qué le parece a usted? ¿Tendrá éxito?

Le mando a usted por correo en dos paquetes certificados La monja y el Martín, cuyas obras no mandé a Es[pasa?] sino a un nuevo editor creyendo que en él hallaría mejores condiciones; pero en vista de que todos son iguales las recogí con la intención de no publicarlas hasta que no lo pueda hacer yo personalmente.

Tendría positiva satisfacción en inaugurarme como editor en Barcelona con alguna obra de usted. ¿Ha desistido usted de escribir sus memorias? He ahí el libro de más popularidad en España y en América que puede usted escribir. Puede usted escribir mucho y bien sobre todo lo que quiera; pero nada alcanzará el número de lectores que esa obra en la que puede usted vaciar lo mismo su sal que sus múltiples conocimientos.

Y basta ya de negocios.

De política excuso hablarle a usted por varias razones, entre otras por mi incompetencia y porque si lo hiciera podría disgustarle quizás.

La apreciabilisima familia de usted está bien. A Lupe la veo tan bien o mejor que antes de sufrir la enfermedad que tanto nos alarmó a todos los amigos. 
En la Mariscala ${ }^{1}$ hace usted una falta inmensa, tanto que yo sólo voy por el cariño que le tengo a la familia, pero no tan animado como antes, porque siempre me vuelvo meditabajo y extrañando unas veces sus consejos y las más su animada y animadora chispa, en la acepción mexicana de esta palabra.

Dicen los filarmónicos nuestros ex compañeros que hacen maravillas con sus instrumentos. Puede ser, pero a un lado la modestia creo que sin los bandolones clásicos que allí faltan y sin la flauta potentísima del infrascrito aquello no puede ir bien.

Sé de más de un académico de la legua que ha tragado más camote que el que produce todo Querétaro en 20 años desde que empezó a recibir de esos hombres pruebas de la consideración que merece, que fue desde que llegó usted a los Madriles, como era natural.

Ya sabrá usted que lo que ahora priva aquí es el arte de la tauromaquia, y puede decirse que no hay ciudadano de buen gusto que no eche al día una conversación de una horita de verónicas, volapiés y demás suertes propias de la gran diversión nacional. Mis aficiones al arte me han conducido al extremo de aplicar en todo, aun en las cosas más serias, el tecnicismo taurómaco. Es de esto que (como diría cualquier dependiente de cajón francés) he hallado fácil explicación a que se hagan de mucho sentido los académicos de por acá; pues a usted le han hecho en un abrir y cerrar de ojos primer espada de cartel de todas las principales plazas y ellos se han quedado como si dijéramos de novilleros de la legua. [i]Es natural que El Mestizo y demás gente menuda que duda por aquí le tengan tirria a Lagartijo, como lo es también que yo no pueda ver ni pintado al titulado bajo Uetam?

Fuera ya de broma, lo felicito a usted cordialmente y felicito cordialmente a los que no tienen calabazas en la vista ni en el corazón y que saben dar a cada uno lo que de derecho le pertenece.

El coronel Sandoval, tan perdido como siempre, vive en una continua orgía con detrimento de la moral pública y horror del género humano. La otra noche vinieron a avisarme que lo tenían preso e incomunicado y que lo habían llevado en unión de otros perdidos y de una runfla de mujeres malas. Resultó que con él estaban presos Álvarez, [i]Forteza [?] y Cruzado, con motivo de un escándalo del que resultaron varios heridos. A la otra lo echo. Por humanidad, por bien de su

\footnotetext{
${ }^{1}$ Se refiere a la suntuosa mansión de Riva Palacio ubicada en la calle de ese nombre.
} 
atribulada familia aconsejé a ese loco; por el camino que va no morirá en su cama.

Consérvese usted sin novedad y ordene lo que guste a su amigo invariable y afectísimo servidor

Santiago Ballescá

[Membrete:] J. Ballescá y Compañía, editores, México, apartado de correos 13, dirección telegráfica: Ballescá.- México.

México 29 de octubre de 1887 Señor general don Vicente Riva Palacio

Madrid

Muy estimado señor y distinguido amigo:

Me ha favorecido la grata de usted 29 del pasado, que contesto, y por la cual me impuse con satisfacción de su regreso a esa después de la excursión veraniega que hizo por el norte.

He admirado las preciosas pinturas de usted y aplaudido las bellezas de todo género en que abundan (lo digo formalmente). El día que edite yo otra obra de usted ya no hará falta Cantó ${ }^{2}$ ni ninguno de sus colegas.

Le doy a usted las más expresivas gracias por la singular prueba de cariño que nuevamente me da usted haciéndome con especial tino algunas reflexiones acerca de los proyectos que en mi anterior le comuniqué. Son para mí de tanto mayor valor sus consejos cuanto profundos son los conocimientos que ha podido usted adquirir de los carácteres de sus paisanos y de los míos y de los medios que hay en cada uno de los dos países para ganar honradamente el dinero.

Idénticas reflexiones viene haciéndome mi padre en una de sus últimas cartas y aun me aconseja que al realizar mi proyectado viaje, para no chasquearme, vaya no con la intención de quedarme sino a estar allí unos cuantos meses como por vía de prueba.

${ }^{2}$ Dibujante que tuvo a su cargo la ilustración de gran parte del México a través de los siglos. 
Cuando en 82 hice un viaje casi con el exclusivo objeto de arreglar lo concerniente a la publicación del México, no tuve ni un solo día de gusto desde que salí de aquí hasta mi regreso, y las palabras de usted vienen a refrescar ahora mi memoria a ese respecto, si bien es verdad que ahora haré mi viaje en otras condiciones, acompañado de mi familia y dejando los negocios bien arreglados.

A pesar de esto no me iré con el propósito de no volver, sino todo lo contrario con la intención de tomar soleta a la patria de mi mujer, de mis hijos y de mis amigos en cuanto me empiece por cualquiera causa a fastidiarme en mi tierra.

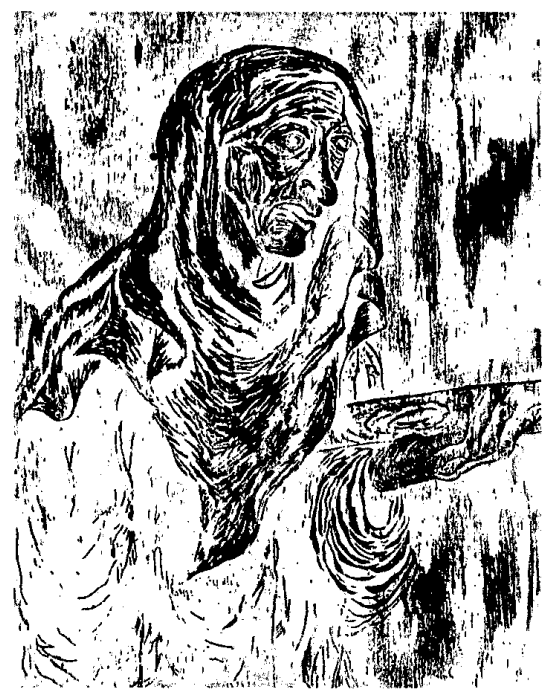

La casa que aquí tengo establecida ni quiero ni puedo traspasarla:

al irme quedaría entregada a los dependientes y sujetos éstos a instrucciones precisas y fijas para cada caso, lo cual no ofrece dificultades a quien como yo conoce el negocio, el país y la gente. Yo desde Barcelona durante el tiempo que allí permanezca mandaré lo que de seguro se pueda vender, adquirido a mejores precios que ahora y con más oportunidad, y desde allí también, recibiendo los borradores de las operaciones diarias que aquí se practiquen veré cómo anda esto y dirigiré el negocio. Que los dependientes se traslimitan de mis órdenes o que veo que el negocio marcha mal, a México la emprendo por el primer vapor y llego a tiempo de evitar cualquier mal grave; pues en un mes, ni en dos ni en seis me lo pueden causar estando como estaré ojo avizor y sobre el cañón. Aunque no cuento con lumbreras entre los dependientes sí los tengo honrados y los que pienso dejar de confianza son Álvarez, Felipe y el [que] llegó de Barcelona poco antes del viaje de usted y los cuales no tendrán otra cosa que hacer que seguir la rutina de la casa y ejecutar mis órdenes. Tales son mis propósitos, que he querido darle a conocer a usted para que me haga el favor de aconsejarme, si le parece que voy errado. 
El retrato que desea usted se reproduzca para la Historia ya está en casa de Cruces: se procurará sacar de êl el mejor partido; pues la reproducción fotográfica es dificil por los colores que tiene.

Vigil no sale de su paso.

La casa J. Ballescá y Cía. ha salido de suantiguo escondite del Amor de Dios para pasar al número $2 \mathrm{del}$ 5 de Mayo, frente al Montepío, a un local seco y bonito, compuesto de un salón bajo y otro alto de 26 metros de largo cada uno y el ancho suficiente para cuatro filas de estantes. Cantó ha sido el director de las obras que se tuvieron que emprender en el local y lo ha hecho muy bien. En local, comodidad y seguri-

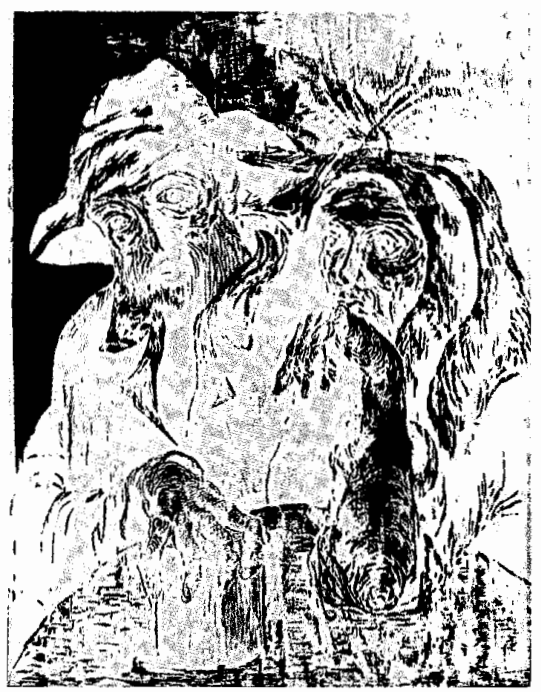
dades de todo género he ganado un $75 \%$. Uno de mis fines al emprender el viaje será establecer librería en forma; pues para ello cuento con mejores elementos que ninguno. En el desarrollo de mis planes tendrá usted que soportar las molestias de ser mi consejero.

Ordene usted lo que guste a su atento amigo y agradecido servidor

Santiago Ballescá 
[9] [Membrete:] José Ballescá, Santa Teresa 8, Barcelona-Gracia, casa en México: J. Ballescá y Compañía, avenida del 5 de Mayo 2.

Barcelona-Gracia 9 de febrero de 1889 Señor general don Vicente Riva Palacio

Madrid

Muy querido señor general:

La grata de usted 28 del pasado me impuso con satisfacción de que sabe que en México siguen en la casa de usted con sus diversiones de siempre, lo que prueba que están bien de salud.

Ya sabe usted que mi vida en México se repartía casi por partes iguales entre mis ocupaciones y la Mariscala. Nada tiene pues de extraño que ya eche de menos aquellas agradables reuniones, en las que jugaba un papel tan principal nuestra inimitable orquesta, cuyos rápidos adelantos debimos todos al maestro don Pancho. El día que nos volvamos a reunir allá, hemos de hacer cosas tan estupendas, que ríase usted de aquellas famosas posadas en las que no quedó nada por pambacear.

El almanaque se lo mandé a usted para que viera nada más la forma; pero ya tenía yo la intención, caso de resolverme a hacerlo, de variarlo como usted me dice y darle atractivo con retratos y vistas de México, artículos de autores mexicanos, etcétera.

Cuando vaya yo a esa, como he de ir solo, ya tendré tiempo de acatarrarlo a usted en grande con mis consultas sobre ese y otros asuntos.

Ya he escrito a México pidiendo informes para calcular si tendrá cuenta hacer la edición del Periquillo. Ojalá que se pueda hacer; pues ya tengo ganas de hacer algo nuevo en que usted tome parte siquiera sea como prologuista.

Si el tomo de poesías no le corre a usted mucha prisa lo dejaremos para cuando nos veamos. Yo creo que las poesías de usted sí pueden venderse muy bien en México. Si quiere usted que en seguida se haga el tomo mándeme las poesías, dígame usted cómo lo quiere por fin y se hará.

En espera de sus gratas órdenes y deseando verlo cuanto antes quedo de usted afectísimo amigo y seguro servidor que besa su mano

Santiago Ballescá 
[10] [Membrete:] José Ballescá, Santa Teresa 8, Barcelona-Gracia, casa en México: J. Ballescá y Compañía, avenida del 5 de Mayo 2.

Barcelona-Gracia 30 de marzo de 1889 Señor don Agapito Ortiz de Jiménez Madrid

Muy querido amigo:

Correspondo a su apreciable del 13.

Agradezco las noticias que me da usted y siento mucho no poder tomar todavía el tren para llegar a esa antes que el señor general vaya a su proyectado viaje; pues el día 25 se embarcó mi padre rumbo a la tierra de usted y cuasi mía, y aquí me tiene usted preso y sin poderme mover del fastidioso escritorio. A mayor abundamiento Cantó ha dado en el mal gusto de enfermarse muy seguido: ahora está en cama con catarro y neuralgia.

El viaje de mi padre, por su edad, es una calaverada; pero se le metió en la cabeza que quería volver a ver México aprovechando mi estancia aquí y se marchó para satisfacer su deseo al mismo tiempo que para emplear el tiempo que esté allá en la reorganización de algo referente a la casa, que no marcha tan bien como sería de desear.

Hágame usted favor de avisarlo al señor general, suplicándole de mi parte que no diga a su casa nada sobre esto.

Le suplico a usted me avise si realiza el general su viaje a Portugal y la fecha del regreso, porque no quiero ir a ésa cuando él no esté.

A Espasa le supliqué que mande obsequiar los encargos del señor general para París. Ya le avisaré a usted el resultado.

El México quedará terminado el mes que entra en el [i]capítulo [?] 157 o 158. El 156 saldrá mañana y con él se armará seguramente mucha bola en México, porque se publica el informe que Escobedo presentó al general Díaz sobre la rendición de Querétaro y la supuesta traición de López.

Recuerdos muy afectuosos al señor general y que me dispense no le escriba por falta de tiempo.

Favor de saludar a su señora, mandando a su afectísimo amigo y servidor

Santiago Ballescá 
[11] [Membrete:] José Ballescá, Santa Teresa 8, Barcelona-Gracia, casa en México: J. Ballescá y Compañía, avenida del 5 de Mayo 2.

Barcelona/Gracia 15 de abril de 1889 Señor general don Vicente Riva Palacio

Madrid

Muy querido señor general:

Vaya ante todo un abrazo por sus días y otro más estrecho porque ya le vi el fin al México. Por la circular que acompaño verá usted que acaba en el [¿̇]capítulo? 157, el cual está en prensa.

Nada he querido poner de todo lo que antes había pensado en la Historia de la Historia, porque de recordar tan sólo las mil porquerías con que embarrándose ellos nos quisieron embarrar a usted y a mí nuestros amigos (?) [sic] sin conseguirlo, se me revuelve todavía el estómago.

Nadie mejor que usted sabe que es cierto cuanto digo en $\mathrm{mi}$ manifiesto. Pero la obra ha concluido, he salido de mis compromisos y ya no me importa, lo digo con sinceridad, lo que haya podido perder en la operación, con tal de verla terminada. Empezamos en la República unos 7000 suscritores y concluimos con 3000 escasamente, debiéndose un número tan considerable de bajas, primero a las circunstancias políticas de cuando empezamos y después a la calma de los señores historiadores, salvo una que otra excepción que yo me sé.

"Cayó el rico imperio de Moctezuma...", 3 dijo no recuerdo quién, y yo agrego:

Pero se salvó la obra México a través de los siglos y con ella el honor de un papelero al que no pudieron hacer mella la audacia de aventureros sin inteligencia y sin decoro etc., etc., etcétera.

Un millón de gracias por todo lo que debo a usted.

Por correo va un paquete que contiene los dos tomos últimos del Talmud y un catálogo de las obras de la Biblioteca que desea usted para que resuelva lo que quiera.

Estoy con cuidado hasta no saber la llegada a México de mi padre y que me dé noticias de cómo encuentre aquello. Mi esposa ha estado muy enferma (un catalán malogrado), y por todo esto he tenido que demorar

3 Palabras iniciales del tomo que escribió Riva Palacio de México a través de los siglos. 
mi viaje a esa, lo que siento mucho, pues tengo hambre de hablar y reír con usted.

Don Manuel Payno me ha propuesto publicar una nueva edición del Libro rojo y me parece buena idea. ¿Está usted conforme? ¿Sería fácil agregarle algo nuevo para hacerlo más interesante y de más volumen?

Ruego a usted me conteste y me diga todo lo que piense acerca de ese proyecto, para hablar con el señor Payno. También me propone unos Apuntes para la historia de la guerra entre México y los Estados Unidos. Se hizo una edición en [18]48, que dice fue secuestrada y mandada quemar por Santa Anna. Es un tomo 40 menor, de más [de] 400 páginas, con algunos retratos y planos.

¿Le parece a usted si se colocaría una edición de 2000 ejemplares, a pesar de la obra que publicó Roa Bárcena?

Basta de preguntas. Perdone mis molestias de siempre y mande usted a su amigo y servidor que besa su mano

Santiago Ballescá

[12] [Membrete:] José Ballescá, Santa Teresa 8, Barcelona-Gracia, casa en México: J. Ballescá y Compañía, avenida del 5 de Mayo 2.

Barcelona-Gracia 23 de abril de 1889 Señor general don Vicente Riva Palacio Madrid

Mi muy querido señor y amigo:

La lectura de la apreciable de usted fecha 19 me ha causado honda pena.

No sé que en mi carta haya estampado cosa alguna que pueda haber herido a usted, pero algo indebido contendrá cuando en la apreciable de usted que contesto hay conceptos que me parecerían muy duros, para dirigirlos a un amigo, si no fuese por el temor que abrigo de haber cometido alguna garrafal indiscreción en mi citada anterior. Si es así le ruego encarecidamente que la dé por no escrita y que me dispense del mal rato que haya podido causarle, teniendo la seguridad de que mi ánimo no fue ése sino proporcionarle a usted una satisfacción haciéndo- 
le saber el término de la obra. Nunca he dicho, ni pensado siquiera, que el mal negocio que con ésta he hecho sea por causa de usted o que usted tenga en ello culpa alguna. Todo lo contrario; tengo la convicción íntima de que si sólo con usted me hubiera tenido que entender, otro bien distinto sería el resultado, y quizás hoy no me acordaría ya de la obra más que para disfrutar los beneficios alcanzados.

Después de todo, casi tendría que felicitarme de haber dado ocasión a la apreciable de usted que tengo a la vista, pues de otra manera habría ignorado siempre los motivos verdaderos que le hacían no escribir las Memorias. Con esta obra quisiera yo ver si es verdad que los libros de usted, exclusivamente de usted, dan buenos o malos resultados editoriales; pero mientras usted no la escriba y yo no la publique tendré que creer que en esto anda usted equivocado, y que por causa de su error me quedo yo sosteniendo que no puede ser verdad el mal resultado de las obras de usted. Si usted quiere haremos la prueba a condición de no decirle cómo resulte, por más que ya lo sepa yo desde ahora.

Quiero suponer que crea usted que mi cariño por la obra que se acaba de publicar sea, como realmente es, grande. ¿Cree usted que a pesar de esto pueda yo tener la convicción de que carezca de muy sensibles lunares? Y como que los tiene, en conciencia no podía yo decir que era un libro perfecto (si es que los hay) y mucho menos podía señalar las partes buenas, las medianas y las malas, explicando al público las causas de tal desigualdad y de que Chavero, por ejemplo, por lo que sólo usted y yo sabemos, afirme en su tomo, en varios casos y contra toda verdad, lo contrario de lo escrito por usted; de que el tomo primero se componga de paja pura y de que en algunos otros se haya dado preferencia a discursos, brindis, etc., etc., con perjuicio de cosas más importantes, tales como la continuación de los capítulos presentando la formación y desarrollo de las ciencias, las artes, la adiministración etc., etcétera. Ni me ha quedado siquiera el recurso de decir de cada uno de los autores lo que cada uno merece, sino que a todos he tenido que tratarlos por igual para evitar que vuelvan algunos a las andadas y me priven de vender la obra completa.

Seguro no expliqué bien mi pensamiento en la circular, y ahora lamento más que la premura con que hube de escribirla y las mil contrariedades que he tenido en estos meses no me dieran lugar para recordarle a usted, antes de mandarla, como pensé hacerlo. Mi intención fue decir a la gente ilustrada, lo más próximo a la verdad; hacerle comprender que la publicación de la obra no ha sido empresa tan 
sencilla, y me pareció que con decir "esta obra ha sido escrita con grande empeño y levantadas miras patrióticas por hombres competentes y honrados, se ha publicado con el esmero que requería su importancia y es la única en que puede estudiarse la Historia patria mexicana", ya estaba dicho que era vano empeño buscar cosa mejor, sin que esta mejoría dependa sólo de que sea más medianito que lo demás que hay escrito sobre Historia de México, sino muy bueno aunque no inmejorable con el tiempo; pues no puede ser malo, ni siquiera mediano un libro escrito con empeño por hombres competentes. No quise decir en absoluto que su mérito consistiera en ser la única, sino en que es la única autorizada por razón de las personas que la han escrito y de las miras con que lo han hecho.

Bien sabe usted que en México se pambacea todo y para evitar que se burlaran de la obra por exageraciones mías preferí pecar de modesto.

¿Qué podrán decir ahora los que no hayan leído la obra? ¿Lo que usted cree? Quizás sí, pero no opinarán de igual modo los que la lean, y si por interés de partido o de nuevo negocio hay quien apoyándose en mis palabras quiera hacer pasar la obra por mala, se le podrá contestar mejor que si yo la hubiera declarado un portento de erudición, aun siéndolo. El que por efecto de mi circular, tan distinta de todas las que suelen dar los editores diciendo cada uno de su publicación que es la mejor habida y por haber, sin que por esto el público lo crea, el que por tal causa, digo, no se decida a comprar la obra tendrá que aguardar para conocer la verdadera Historia de México, a que se escriba y se publique la que venga a hacer menor el mérito de la nuestra. [¿]El que tal haga y el que niegue a esta todo el mérito que tiene se parecería, según yo entiendo las cosas, al que no quisiera oír a Gayarre? o a la Patti presintiendo que los nietos de éstos (caso que los tengan) han de cantar mejor que ellos.

Conste que nada de lo que aquí digo lleva pretensiones de discutir con usted de lo que me guardaré yo bien, sino explicarle tan sólo lo que pensé al escribir la circular, de la que estoy más arrepentido que de mis pecados.

Para concluir esta carta (me parece ver la cara que pondrá usted al mirar sus dimensiones) le ruego que me diga claris verbis cuanto tenga que decirme, indicándome lo que deba yo hacer para remediar las faltas en que involuntariamente haya incurrido, porque no puedo conformarme con el temor de haberle causado a usted ninguna ofensa y que la 
amistad con que me honra hace tantos años venga a menos por tonterías mías.

Ruego a usted me conteste cuanto antes.

Termino esta hoy día 4 de mayo, pues el 23 me enfermé de la garganta y he estado en cama hasta ayer.

Le desea a usted muchas felicidades su afectísimo seguro servidor y amigo que besa.su mano.

Santiago Ballescá

[13] [Membrete:] José Ballescá, Santa Teresa 8, Barcelona-Gracia, casa en México: J. Ballescá y Compañía, avenida del 5 de Mayo 2.

Barcelona-Gracia 24 de mayo de 1889 Señor general don Vicente Riva Palacio Madrid

Mi querido señor general:

La grata y muy apreciable de usted fecha 7 me tranquilizó por completo por lo que hace a la pena que me había causado la lectura de la anterior carta que se sirvió usted dirigirme.

Ahora sólo deseo que tenga usted las explicaciones que le di como una expresión sincera de lo que realmente siento.

Ya verá usted como el crédito de la obra aumentará ahora que la gente empiece a leerla. Espero que se vendan muchos ejemplares completos especialmente entre los ayuntamientos y los gobiernos de los estados; pues entiendo que nuestra obra debe figurar en donde quiera que haya obligación de saberse la historia de México.

Razón tiene usted de sobra para lo que dice y para mucho más comparando lo que con usted y conmigo en mi humilde esfera hizo el gobierno, y lo que hacía con esa horda de pillos cuya única habilidad consiste en saberse arrastrar a los pies del que manda.

Quizás dentro de muy pocos días tenga yo el gusto de abrazarlo a usted y entonces hablaremos de todo, especialmente de las Memorias. 
Muy pronto voy a mandarle a usted una caja con los 7 ejemplares del "México" por cuenta del gobierno.

Por correo va un paquete con 4 ejemplares [de las] Tradiciones que son los que ahora tengo. Si necesita usted más hágame favor de avisarme.

Deseándole a usted muchas felicidades, quedo como siempre de usted afectísimo amigo y seguro servidor que besa su mano

Santiago Ballescá

Creí poder salir hoy para esa y con tal esperanza guardé la presente pero no pudo ser.

[14] [Membrete:] José Ballescá, Santa Teresa 8, Barcelona-Gracia, casa en México: J. Ballescá y Compañía, avenida del 5 de Mayo 2.

Barcelona-Gracia 6 de julio de 1889 Señor general don Vicente Riva Palacio

Madrid

Mi muy querido amigo y señor:

Ayer recibí carta de un amigo de México y me cuenta que el señor Altamirano ha sido nombrado cónsul general en España en sustitución del señor Payno que pasa a París, y que nuestro amigo el señor Antuñano irá de cónsul a Santander, porque si bien Altamirano está facultado para fijar su residencia en esa corte o en este puerto, según le convenga, parece que está decidido a establecerse aquí para cuidar de la impresión de sus obras.

Desde que se supo aquí que el señor Payno había sido promovido al consulado general de Francia, y aun antes de esto, cuando el señor Payno deseaba fijar su residencia en esta ciudad, temí que trasladaran al señor Antuñano a otro punto y me permití indicarle la conveniencia de que diera algunos pasos con el fin de ver si conseguía que le dejasen con su actual empleo aun en el caso de que el consulado general radicase aquí. La cortedad de carácter del señor Antuñano ya la conoce usted y así no se extrañará que se negara a solicitar algo en el sentido indicado 
acudiendo a usted en súplica de que pusiera de parte de él su poderosa influencia, con lo que indudablemente habría conseguido lo que deseaba, y esto sin perjudicar a nadie, pues aunque nada entiendo de esos asuntos creo que la residencia del cónsul general en ésta no sería incompatible con la del cónsul actual. No quiso Antuñano molestar a usted por no abusar de la bondad con que le trata, por lo cual y por fiar en promesas de gentes que ninguna influencia pueden tener se halla ahora abocado a tener que ir a Santander, si es cierto lo que me han dicho.

No crea usted que le escribo yo la presente por encargo de Antuñano ni siquiera de acuerdo con él, que se conforma y respeta y acata cuanta orden reciba de su gobierno. Le escribo a usted porque sentiría mucho ver partir de aquí tan buen amigo, como lo sentirían cuantos tienen negocios con este consulado que desempeña Antuñano en condiciones que el mejor no podrá superar, y le escribo a usted también por la seguridad que tengo de que el clima de Santander no producirá ningún bien a la quebrantada salud de nuestro citado amigo.

Si está usted conforme con cuanto dejo dicho, le estimaría muy mucho que hiciera algo en bien de Antuñano, cuya remoción al consulado de Santander no me parece un ascenso digno del antiguo, honrado y cumplido cónsul de Barcelona.

[Documento incompleto]

[Membrete:] José Ballescá, Santa Teresa 8, Barcelona-Gracia, casa en México: J. Ballescá y Compañía, avenida del 5 de

Mayo 2.

Barcelona-Gracia 12 de julio de 1889 Señor general don Vicente Riva Palacio

Madrid

Muy estimado señor y amigo:

La estimada de usted de anteayer me ha dejado como quien ve visiones, porque ni remotamente sospechaba que emprendiese usted tan pronto un viaje a México. Lo siento por mí, porque de seguro va usted a estarse mucho tiempo por allá, y sin falta ni excusa de ninguna clase pensaba yo 
ir a ésa tan pronto como volviese usted de su paseo en otoño, ya que me ha sido imposible ir antes por la ausencia de mi padre. Por usted y por su apreciabilísima familia me alegro remucho, sintiendo remucho más no poderle acompañar y dar a todos los estrechos abrazos que ahora usted hará favor de llevarles de mi parte. Me parece estar viendo las fiestas que se armarán en la Mariscala, aunque no dejo de reconocer, pese a mi modestia, que en las grandes funciones de ópera notarán la falta irreparable de un buen bajo y en los conciertos musicales, digo instrumentales, la de mi flauta sin igual.

Tenga usted un viaje muy feliz y goce usted mucho en México, sin olvidarse de volver.

Las cosas que dice usted hubiéramos arreglado, las arreglaremos en cuanto regrese usted.

Celebro que la opinión de usted respecto del señor Antuñano concuerde con lo que me permití decirle en mi anterior. Tanto mejor para nuestro citado amigo.

Deseándole muchas felicidades le mando a usted un fuerte abrazo de despedida su afectísimo amigo y seguro servidor que besa su mano

Santiago Ballescá

[16] [Membrete:] José Ballescá, Santa Teresa 8, Barcelona-Gracia, casa en México: J. Ballescá y Compañía, avenida del 5 de Mayo 2.

Barcelona-Gracia 23 de julio de 1890 Señor general don Vicente Riva Palacio

Madrid

Mi querido señor general y distinguido amigo:

Como de costumbre se me agrió este año mi tantas veces proyectado viaje a ésa, y lo que siento más es que ahora quería ir para salir de una duda. ¿Está usted enfadado conmigo?

¿He podido cometer algún acto que merezca el enojo de usted al grado de ignorar si recibió usted el encargo que me hizo desde París y la carta que le dirigí a la misma capital antes de su partida para México? 
Si está usted enojado y el motivo lo considera tan grave que no tenga disculpa escrita, dejaré el desagravio para cuando quiera Dios pueda yo ir a ésa; pero si es por causas leves me comprometo a escribir cuantos pliegos sean necesarios en descargo de la filipica que tenga usted a bien dirigirme y que con ansia aguarda su invariable amigo $y$ servidor que besa su mano

Santiago Ballescá

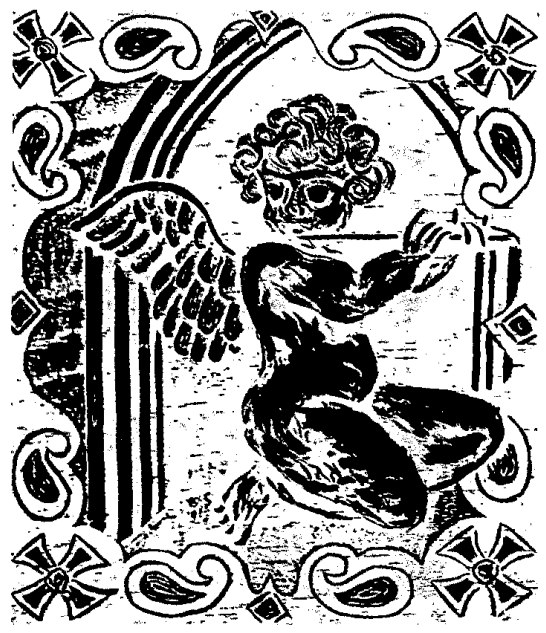

[17]

Barcelona, noviembre $7 / 90$.

Señor general don Vicente Riva Palacio Madrid

Mi muy querido señor general:

Para poder contestar la estimada de usted [de] 27 de julio ha sido preciso que me pusiera como usted estaba cuando me dirigió aquella: enfermo de la cara y preso en casa. Deseo que sea mi caso de simpatía y que el mal haya pasado de la de usted a mi cara.

De a tiro me amoló usted con su grata citada.

Eso se llama ir por lana, etcétera. Ya no quiero buscar excusas para disculparme con usted; pero conste que si me permití preguntarle que si estaba enojado conmigo fue porque realmente le dirigí una carta a París contestando el telegrama que me mandó usted pidiendo un ejemplar [del] México de gran lujo, que le remití.

Usted no querrá creerlo, pero de tal manera absorben toda mi atención los enojosos asuntos de mi casa de México que no me queda tiempo para nada y menos para desprenderme de aquí un momento. Aun sin contar con el interés de verlo a usted, que es grande, me urgía ir a esa por mis negocios. No sólo, sino que tomé una casa en un pueblo de la 
montaña para llevarme la familia siquiera un mes y no la llevé ni un día, a pesar de ser necesario a la salud de toda mi gente.

No quiero ya hablar de viaje a ésa. Puede que antes me vaya a la Gran Tenoxtitlán, cuyos recuerdos se avivan más cada día en mí.

Si cuando me escriba usted quiere dedicar algún párrafo a hablarme de su estancia en México y de su apreciabilísima familia, me causará usted un bien porque no los olvido y deseo que todos se conserven sin novedad para que volvamos a vernos reunidos en fiestas tan incomparables como aquellas posadas, $o$ en las comedias que yo destrozaba

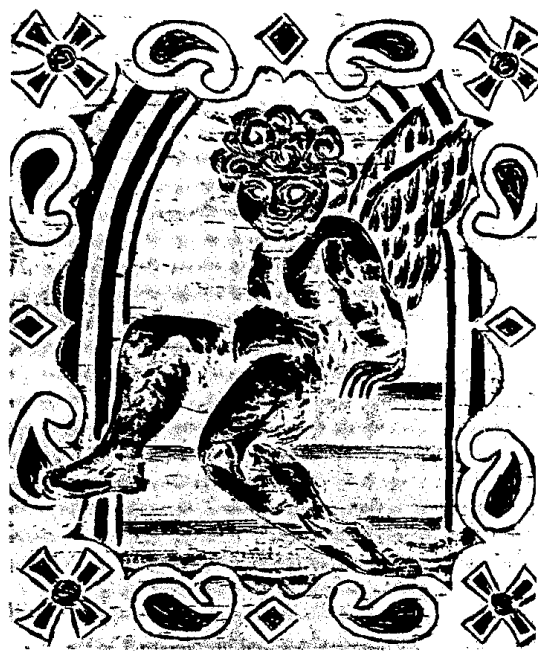
tan sin piedad emulado por los demás artistas mis compañeros.

He echado en olvido voluntario el encargo de usted de buscar libros raros porque por más que los he encargado no salen. No es esta plaza para el caso. Estaré a la mira de lo que pueda salir.

Desde que cambió la pluma por el pincel le ha entrado esa flojera que antes no se le conoció a usted. Las bellas letras deben de tener ojeriza a las bellas artes por causa de usted. Yo no me opongo a que siga usted rindiendo culto a aquella afición; pero, hombre, ique comamos todos! como dice el sepulturero de "A casarse tocan".

¿He de conseguir yo de usted lo que no alcanzan las personas que menciona en la grata que contesto?

Dice usted que escribir es rascar. Nadie mejor que yo sabe lo cierto que esto es tratándose de usted, que rascando ha escrito siempre todo lo que ha querido. Lo que tiene es que ahora no le pica.

Perdone usted la broma, mi querido general; quiero ver si haciéndolo enfadar le viene la comezón y resulto mejor sinapismo que esos señores.

Cuando se halle usted en disposición de empezar, temas y asuntos no le faltarán. ¿He de indicarlos yo? Líbreme Dios de cometer tal pecado.

Lo único que puedo hacer es recordar a usted que hace próximamen- 
te un siglo aguardo unas Memorias, que no olvido. Escritas según el plan que había usted trazado resultarían un manjar de padre y muy señor mío. Serían como un inmenso molde en el que vaciase usted a la vez su sal inagotable, las bellezas de su lenguaje y esos pequeños conocimientos que posee en todos los ramos del saber. Y no digo más sino que empiece usted a rascar.

Si ya no le gustan las Memorias, ¿qué le diré a usted que escriba? Historia seca y sesuda no lo aconsejaría a usted, por lo mismo que usted dice que pocos la entienden, y a nadie le hace gracia romperse la cabeza para que se lo agradezca la posteridad, dándose el caso de aquella definición de la gloria que hizo usted en un magnífico soneto. ${ }^{4} \mathrm{Sin}$ embargo, hay sus distingos. Si todos los tomos del México fuesen como el segundo, otro fuera el renombre de esa obra.

¿Quiere usted volver a escribir novela? Pues, hágala usted de costumbres y titúlela "Los misterios de México", o como quiera, seguro de un gran éxito. Eso sí, escríbala o no le ruego que se reserve ese título, para que no nos salga mañana con él un escritorzuelo cualquiera. Es título que hace tiempo tengo entre ceja y ceja. basta.

Lo que sea pero escriba usted luego algo, que siendo de usted ya

Por Dios, no me alegue usted el éxito del Fistol para reprocharme que no haya yo querido entrarle al Periquillo. Usted lo dice; este es un libro clásico y por esto le tuve miedo. Aquél me parece que no tiene nada de clasicismo y a esto se debe su éxito, si es que lo ha tenido, en cuyo caso será entre gente cuya admiración no debe usted ambicionar.

No quise el Periquillo, porque lo que yo quiero es una obra de usted, pura y exclusivamente suya, para editarla pura y exclusivamente yo. Hasta hoy ha andado usted en malas compañias en todo lo que ha escrito para mí. Esto nos ha perjudicado a los dos, más a usted que a mí, y a mí me ha perjudicado no ser el verdadero editor de sus libros. Así, aunque éstos hayan alcanzado mucho éxito los que han ganado más han sido los que han hecho menos. Pregunte usted a Espasa. Si el México hubiera sido escrito por usted solo y editado por mí, con eso salgo de pobre.

Conque ¿rasca usted?, ¿sí o no?

${ }^{4}$ En ese soneto Riva Palacio resume la gloria póstuma de quienes no la gozaron en vida, en la fórmula: "Al asno muerto, la cebada al rabo." 
Toda la troupe de esta su casa le saluda con cariño.

Suyo de corazón amigo y servidor

Santiago Ballescá

Muy querido señor general:

Antes no era yo perezoso para escribir, pero lo que es ahora no hay quién padezca más aguda la enfermedad de que usted se lamenta, que éste su humilde amigo y servidor. Semanas enteras se me pasan sin hacer nada de provecho, y si en compensación de mi falta tenía antes alguna actividad, vista buena y pulso firme, ahora ni de eso puedo alabarme, lo cual me indica que voy para viejo antes de tiempo.

Celebro mucho las buenas noticias que se sirve usted darme de su estimada familia, con el solo pero del casamiento de la apreciabilísima Pilar con Pepe Cosío, contra la voluntad de todos. Ojalá que no se equivoque usted y que sepa éste apreciar las prendas que tan simpática hacen a Pilar.

Me dio usted varios alegrones con su grata del 12, y el mayor de todos es el de su próximo viaje a ésta, que deseo sea de veras muy pronto y no como los míos a ésa. En esto hay egoísmo de mi parte, pero no egoísmo de editor sino de amigo, porque para todo lo referente a las Memorias no es preciso que nos veamos ahora sino cuando vayan a imprimirse. Lo que quiero es abrazarlo a usted, hablar mucho y de todo, pasearnos juntos tanto como usted quiera y pueda, para llevarme esos recuerdos gratos si es que realizo mi viaje a México, pendiente para fines del entrante o principios de enero. El objeto principal que ha de llevarme a México por una temporada es el traslado de almacén, porque en el actual no caben más papeles; pero hay mucha demanda y oferta ninguna de locales grandes y temo que no encuentren el que he encargado. Si lo encuentran me telegrafiarán y harán las obras que sean necesarias conforme a mis instrucciones, a fin de que a mi llegada se pueda proceder sin demora al traslado. Pero si no se encuentra el local por todo el mes que viene, 
tendré que diferir mi proyecto, porque yo necesito estar de vuelta aquí, a más tardar, a fines de abril, en cuya fecha me regalará mi mujer la sexta edición, o el tomo sexto de mis obras. ${ }^{5}$ Estoy, pues, amoladito y sin poder disponer libremente de mi persona ni llevarme para allá mi gente.

En Madrid debe hacer ahora un frío horroroso, y la mayor parte del tiempo lo pasará usted junto a la chimenea. Véngase usted una temporada a mi tierra para cumplir el compromiso que tiene con el conde de San Juan y para huir de ese foco de microbios de todo género. Aquí podrá usted prescindir de la chimenea y salir siempre que quie-

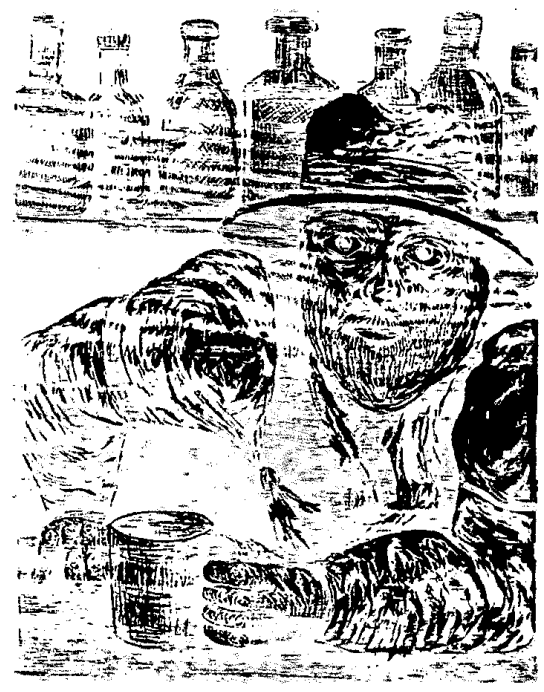
ra sin necesidad de cubrirse de pieles. ¿Nos dará usted el placer de verle por aquí?

Otro gusto mayúsculo me ha dado usted con la promesa de que va a principiar las Memorias. Las publicaremos de una manera digna y harán furor. Hágame usted favor de ordenarme todo lo que crea necesario para preparar la publicación, cuando lo juzgue oportuno. En el Monitor de 22 octubre hallé el suelto que acompaño: debe haberlo escrito algún amigo de usted para animarlo a escribir.

Lo que le conté a usted tener en tratos fueron algunos miles de tomos de una biblioteca llamada de Verdaguer, parecida a la de "Arte y Letras"; pero al fin no la compré porque resultó que estaba trunca; es decir que había pocos ejemplares de títulos buenos y se contaban por miles los de poca venta.

Toda mi gente agradece mucho los recuerdos de usted y me encarga saludarle muy afectuosamente. A mi vez, me permito suplicar a usted igual encargo para el amigo don Agapito.

Mis muchachos van creciendo y desarrollándose a pesar de sus enfermedades. Aunque en esta su casa se habla el castellano usual, ellos

${ }^{5}$ ¿El sexto hijo de Ballescá? 
suelen ya mezclar algunas palabras de origen sospechoso, de aquellas que tanta gracia le hacen a usted.

Esperando tener el gusto de darle muy pronto un estrecho abrazo, me repito a sus órdenes afectisimo amigo y seguro servidor que besa su mano

\section{Santiago Ballescá}

Cuando emprenda usted el viaje hágame favor de hacer que me avisen oportunamente.

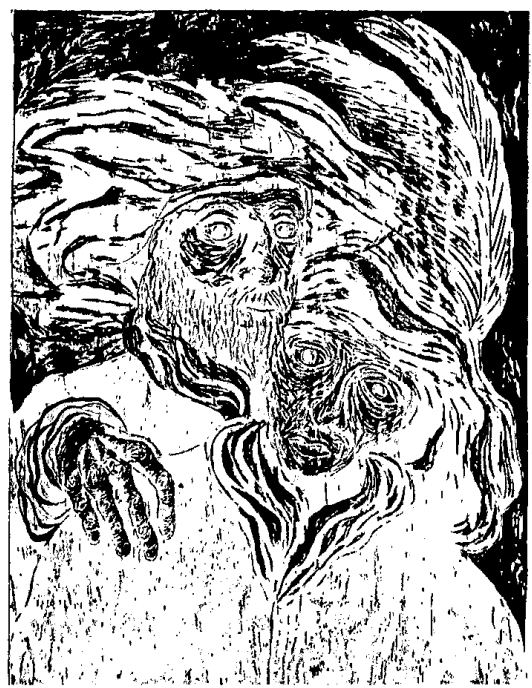

[19] [Membrete:] José Ballescá, Santa Teresa 8, Barcelona-Gracia, casa en México: J. Ballescá y Compañía, avenida del 5 de Mayo 2.

Barcelona-Gracia 8 de febrero de 1891 Señor general don Vicenté Riva Palacio Madrid

Mi querido señor general:

Con intervalo de un día he recibido sus muy estimadas de 6 y 7 de éste, y la verdad es que no sé qué contestar, de momento, a las preguntas que me dirige usted. Las dos me halagan mucho por lo que tienen de honrosas para mí y por probarme nuevamente que en nada ha decaído el aprecio con que siempre me distinguió usted.

Los consejos que me dio usted en su apreciable fecha 4 de diciembre último pesaron tanto en mi ánimo que desistí de mi proyectado viaje a México. Al hacerlo hube de variar por completo mis planes, y a trueque de no pocos sacrificios dispuse todo lo necesario para que sigan los dependientes y la casa tal como estaban, para evitarme el viaje; de suerte 
que por lo que hace al negocio no tengo ya necesidad de ir a México, por ahora, y en esta inteligencia vive toda mi familia, que veía con muy malos ojos mis preparativos, oponiéndose constantemente a mi marcha.

El pensamiento de un viaje con usted es capaz de tentar a un santo y a fe de Ballescá le digo que a ser un poco menos esclavo de mi numerosa familia y de los negocios que me proporcionan lo necesario para sostenerla, desde luego contestaría afirmativamente la pregunta de usted. Ahora me tengo que conformar con la idea de que quizás de aquí a la fecha que usted señala varien algo las cosas y me sea dado alcanzar la doble satisfacción de ir a México y de ir con usted, lo cual habría sido segurísimo si lo que ahora me anuncia lo hubiera yo sabido dos meses antes.

Lo que sí le puedo asegurar a usted es que antes de marchar usted hemos de vernos, aunque usted no venga a Barcelona.

Esperando hablar con usted aquí de ello, como me dicta en su grata, no había contestado referente a la proposición del licenciado don Eduardo Ruiz. Sin dudar de las buenas condiciones que tenga la obra de que se trata y a reserva de hablar detenidamente con usted, creo que como negocio no ha de ser bueno, por tratar sólo de una región y por lo de la parte antigua, sobre todo. Creería yo más seguro y general el éxito si tratara sólo acontecimientos modernos, como el de la guerra con los franceses. De todos modos hablaremos.

Ya que en una de sus estimadas me cita usted a Vigil, permítame usted una confidencia. Ya sabe usted lo que ese señor me hizo sufrir por su grandísima calma en la entrega de originales y las pérdidas materiales que esto me causó. Entre tanto iba él pidiendo dinero cada mes, que yo le daba porque de otro modo no habría escrito poco ni mucho, pues según me tenía dicho necesitaba contar con un tanto fijo mensual y de no dárselo yo, tendría que escribir para algún diario. En vísperas de mi salida de México, temiendo que me dejase colgado acepté sus proposiciones de escribir una obra completa referente a la Reforma, tan pronto como acabara el México, y que él seguiría cobrando en mi casa la mensualidad hasta completar la cantidad de $\$ 1350$ por su tomo de aquella obra y nada menos que \$2000 por la nueva: total \$ 3350 que ha recibido en buena moneda, sin que hasta la fecha sepa yo que haya entregado una'sola hoja de original de su novísima anestésica producción. Esto último me tiene sin cuidado, porque no creo que sea el hijo de mi madre el que se meta a publicar tal cosa. Lo que quise asegurar con aquel sacrificio fue la conclusión del México, y nada más. Y no digo más 
por no decir lo que pugna por salir de mi cabeza hablando de aquel señor.

Por ser hoy domingo no he podido ver a un amigo para hablarle de la magnífica idea de usted referente a la publicación de un periódico que sea órgano oficial de la Junta del Centenario. La idea me asusta y me halaga a la vez, porque creo, como usted, que es un negocio seguro; pero se necesita capital y yo solo no podría, tratándose de una cosa digna del pensamiento y del objeto. Mañana mismo me ocuparé empeñosamente en ello y en seguida le escribiré o telegrafiaré. Ojalá que pueda yo tener la honra de tener parte en publicación tan importante y de todos modos siempre tendré que agradecer a usted que se haya acordado de mí para una empresa de tal magnitud.

Me despido de usted hasta mañana repitiéndome suyo afectísimo servidor y amigo que besa su mano

Santiago Ballescá

[20] [Membrete:] José Ballescá, Santa Teresa 8, Barcelona-Gracia, casa en México: J. Ballescá y Compañia, avenida del 5 de Mayo 2.

Barcelona-Gracia 10 de febrero de 1891

Señor general don Vicente Riva Palacio Madrid

Mi querido señor general:

En respuesta a mi telegrama de ayer recibo ahora el de usted en que se sirve decirme que me aguarda, lo que agradezco debidamente.

Hablé con Espasa y se manifestó desde luego dispuesto a entrar en el negocio; pero como no pude darle ningún dato ni pormenores, acordamos que pasara yo a esa para hablar con usted sobre el asunto y comunicarme después con él para resolver en definitiva. Creo que no habrá dificultad y que podrá hacerse una cosa superior y digna del hecho que se trata de conmemorar, siempre que pueda contarse con la dirección de usted o de persona de toda su confianza que disfrute de la influencia necesaria para que no lleguen a faltar los elementos de que se 
haga cuenta al formular el programa respectivo, que supongo será amplísimo.

Un resfriado mal cuidado se me ha convertido en bronquitis y por este motivo no he podido ponerme en camino en seguida. Espero estar bien el sábado para marchar en el express de ese día. El sábado, pues, le telegrafiaré a usted mi salida, o en caso contrario el motivo que me impida ir (que espero no lo habrá) para que disponga usted lo que tenga por conveniente.

Dada la importancia del asunto creo que no es fácil tratarlo por cartas, queriendo hacer una cosa que se separe de lo vulgar y que contribuya poderosamente a dar realce a todos los actos de la gran fiesta que se prepara.

El domingo tendrá la satisfacción de darle un abrazo su siempre adicto amigo y seguro servidor que besa su mano

Santiago Ballescá

Barcelona, febrero 23/91

Señor general don Vicente Riva Palacio

Madrid

Mi muy querido señor general:

Acabo de recibir la grata de usted en que me avisa el acertado acuerdo que resultó de la entrevista que tuvo con los señores Valera y Linares Rivas. Creo que ese acuerdo, con todo lo demás que se sirve usted decirme, en nada mermará la respetabilidad de la publicación.

Celebro haber recibido tan pronto la estimada de usted, porque esta tarde debo reunirme con Espasa para tratar el asunto, y las disposiciones que me comunica usted formarán parte del programa que debo presentar.

Preveo que la publicación de que se trata le va a ocasionar a usted mucho trabajo, quizá más de lo que usted se figura; pero servirá de enseñanza a los asuntones que en todas partes ven montañas inaccesibles, y de satisfacción para mí que estaré en continua comunicación con usted si, como creo y deseo, se lleva todo a cabo por la casa citada o por otra que busquemos en defecto de aquélla.

Por mi parte ofrezco a usted archivarlo todo para mandar cuanto 
antes el proyecto en forma, muestras, etcétera.

También me ocuparé de los encargos de usted.

Lo del libro fue muy sencillo. Dije a Real y Prado que me había hecho cometer una plancha muy fea y que era preciso ver de repararla. Sabía él de la existencia de otro ejemplar y lo consiguió en condiciones aceptables, cumpliendo entonces mi encargo de mandárselo a usted sin necesidad de haber caído en el timo que se nos había preparado.

Vine a encontrarme con dos de mis muchachos enfermos; pero parece no será nada.

Todas mis gentes reconocidas a las infinitas atenciones que me prodigaron usted y el excelente amigo Agapito, saludan a ustedes con igual cariño que su agradecido amigo y servidor que besa su mano

Santiago Ballescá

Ya he hablado largamente con Espasa y socios. Pronto irán muestras de todo y proyecto en forma.

Barcelona, marzo 21/92 Señor general don Vicente Riva Palacio

Madrid

Mi querido señor general:

La estimada carta de usted fecha 15 me ha llenado de satisfacción, pues me demuestra que se interesa usted por mis asuntos, lo que le agradezco sinceramente. 
Estoy completamente de acuerdo con cuanto usted me dice y creo que no hago mal en ir a dar una vuelta por México para esperar luego, más tranquilo, el día del regreso definitivo con toda mi gente.

También yo creo que en el tomo 20 del México hallarían mucho y mucho que alabar y admirar los que han aplaudido el discurso de usted.

Una de mis mayores satisfacciones en México será la de volver a ver a su estimada familia, y sólo sentiré que no pueda ir a pasar ratos de aquellos que pasábamos usted y yo, vis a vis, en su estudio. Supongo que no piensa usted eternizarse en Madrid, y por consiguiente espero que aquellos tiempos volverán.

Disponga usted de su afectísimo amigo y seguro servidor que besa su mano

Santiago Ballescá

Marzo 22/92.

Acaba de favorecerme la grata de usted del 20 .

Mil gracias por sus frases de cariño.

Si hoy no me traen la caja la mandaré recoger.

[23]

Barcelona, septiembre 22/92 Señor general don Vicente Riva Palacio

Madrid

Muy estimado señor y amigo mío:

No fue posible escribirle a usted desde México: llegar allá y empezar a trabajar sin descanso hasta el instante de subir al tren para mi regreso, todo fue uno.

Renuncio, por no molestar a usted, a referirle los disgustos que pasé, especialmente con el famoso Sandoval. Resultó lo que usted y yo temíamos hace tiempo.

Al emprender mi marcha a México llevé intenciones de permanecer allá un par de meses, dedicándome sólo a remendar desperfectos y a ver por qué medios podría dar mayor impulso a los negocios de mi casa; pero quiso la casualidad que al llegar yo se desocupase el local de Santa 
Isabel, que tuvo durante muchos años la Sociedad Filarmónica Francesa, y no quise perder tan espléndida ocasión para instalar mis almacenes en un solo sitio. Emprendí, pues, la obra colosal del traslado y me marché con la satisfacción de dejar instalado el nuevo almacén de una manera que daría envidia a cualquiera de su género en el extranjero.

Para que se forme usted una idea del trabajo que supuso el traslado bastará decirle que se llenaron, mejor se rellenaron a más no poder, unos 200 carros de los de cuatro ruedas. Todos los cuadernos y libros se revisaron e inventariaron, ocupando una extensión de 400 metros de estantería de tres metros de altura.

El techo del local, como de iglesia, es elevadísimo; de suerte que al volver yo mañana a México no tengo que hacer más que subir los estantes y formar galerías altas si quiero o puedo realizar mis planes de establecer una gran imprenta, litografia, etc., etcétera.

Con eso del traslado permanecí en México algo más de tiempo de lo que yo había pensado y tuve que volver por Nueva York para llegar aquí con el menor retraso posible, privándome esto de la satisfacción que había acariciado de desembarcar en Santander y pasar por ésa para darle a usted un abrazo y manifestarle mi profundo pesar por la irreparable desgracia que han sufrido usted y toda su apreciable familia.

A su estimable señora, que ha dado pruebas de ser una verdadera heroína, tuve la pena de darle un abrazo de despedida la víspera de mi marcha, dejándola bien de salud y hasta cierto punto resignada. Ojalá que después haya seguido lo mismo.

Los negocios en México estaban mal y han seguido después en completa calma. Nosotros vendemos hoy exactamente la mitad de lo que vendiamos hace un año.

Lo supongo a usted muy ocupado con lo del Centenario y no quiero molestario más.

Consérvese usted bien y ordene lo que guste a su afectísimo amigo y seguro servidor que besa su mano

Santiago Ballescá 
Mi querido señor general:

Mucho le agradezco a usted que en medio de las muchas ocupaciones que tiene se haya servido contestar mi carta.

Ojalá que realice usted el pensamiento que tiene de hacer venir a su lado a su estimable señora, pues creo que fuera lo mejor para todos, hasta para los amigos de usted, que en vez de perderlo a usted ganarían teniendo el honor de conocer y tratar a su digna compañera.

También la tienda la trasladé al nuevo local, pues recordará usted que a la parte de la calle había unas piezas que servian de tocador, las que convertí en un solo salón, y allí instalé, hasta con lujo, la librería y el despacho.

La tranquilidad de Felipe llegó hasta más allá de lo que usted cree. Después de haber descubierto yo sus trampas y de haberlo echado amenazándolo con meterlo a la cárcel, todavía tenía humor para andar con los cómicos que habían sido causa de su estrafalario proceder. Todavía no se ha practicado la liquidación que ha de darnos a conocer el monto de la estafa que yo calculo en 9000 o 10000 pesos, de los que sólo cobré 600. Hay esperanzas de cobrar otros 4000 .

Todo lo que usted me dice para animarme a pasar unos días en esa es muy tentador, tanto que no haré falta a no impedírmelo algún suceso imprevisto.

Con afectos de toda mi familia se repite de usted afectísimo seguro servidor que besa su mano

Santiago Ballescá 
Mi querido señor general:

La estimada y cariñosa carta de usted fecha 26 ha influido no poco en mi ánimo para darme el valor que es necesario para sufrir resignadamente la desgracia que he tenido, tanto más sensible cuanto que vino cuando nada la hacía temer. Muchísimas gracias por la parte que toma usted en mi dolor.

Supongo que nuestro buen amigo Pancho Sosa le escribiría a usted de su estancia en ésta, que procuré contribuir a hacerle grata. Después de su marcha no he vuelto a saber de él y creo que no tardará en volver, pues me ofreció que vendría a embarcarse aquí. Me habló de unos proyectos de usted referentes a unas publicaciones y especialmente de las Memorias tan deseadas. A esto no tengo que contestar sino que disponga usted lo que quiera, pues ya sabe que sus deseos son órdenes para mí y además siempre he creído que las Memorias han de meter mucho ruido el día que salgan.

Es muy sensible todo lo que ha pasado con las fiestas del Centenario por falta de empeño y buena dirección. Del famoso periódico no hay ni que hablar. iQué diferencia si nos hubieran confiado a usted la dirección general y a mí la material! Vale más que no haya sido, porque para gloria usted ya tiene bastante y a mí no me hace falta a cambio de los sinsabores que nos habrían causado esos señores.

Al artista le trasmití oportunamente lo que me dijo usted.

Que tenga usted noticias buenas de su estimada familia y que se conserve usted bien le desea su afectísimo amigo y seguro servidor que besa su mano 


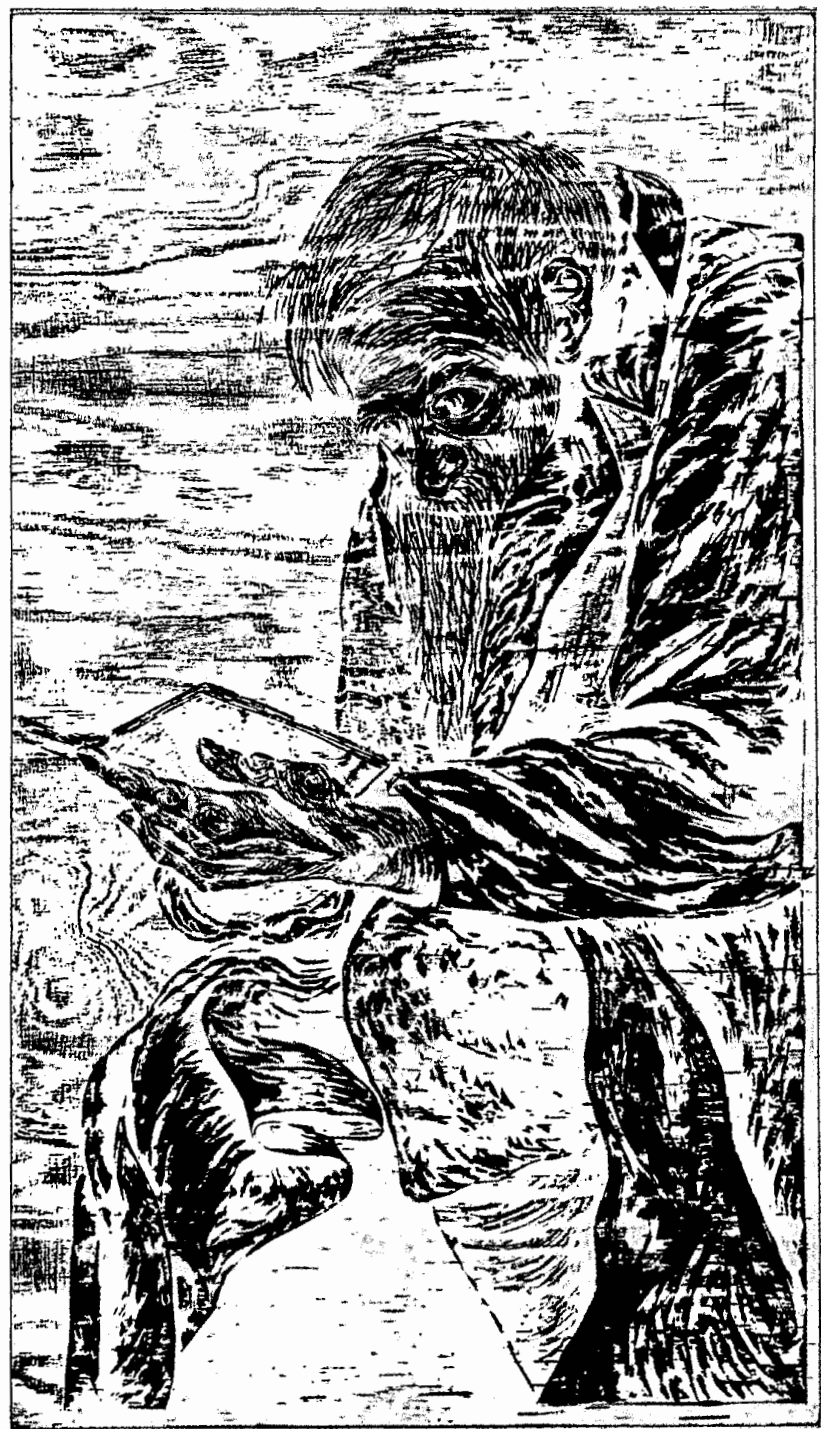

